\title{
Effects of Kimchi Powder on the Quality Properties of Emulsion Type Sausage Made with Irradiated Pork Meat
}

\author{
Sun-Mi Choi ${ }^{1}$, Ji-Hun Choi², Yun-Sang Choi ${ }^{3}$, Hyun-Wook Kim ${ }^{1}$, Hack-Youn Kim², \\ Mi-Ai Lee ${ }^{5}$, Ko-Eun Hwang ${ }^{1}$, Ju-Woon Lee ${ }^{6}$, and Cheon-Jei Kim ${ }^{1,4 *}$ \\ ${ }^{1}$ Department of Food Science and Biotechnology of Animal Resources, Konkuk University, Seoul 143-701, Korea \\ ${ }^{2}$ Food and Industrial Ingredients Center, CJ Cheiljedang, Seoul 152-050, Korea \\ ${ }^{3}$ Food and biological Resources Examination Division, Korean Intellectual Property Office, Daejeon 302-701, Korea \\ ${ }^{4}$ Research Institute for Meat Science and Culture, Konkuk University, Seoul 143-701, Korea \\ ${ }^{5}$ World Institute of Kimchi an Annex of Korea Food Research Institute, Seongnam 463-746, Korea \\ ${ }^{6}$ Team for Radiation Food Science and Biotechnology, Advanced Radiation Technology Institute, \\ Korea Atomic Energy Research Institute, Jeongeup 580-185, Korea
}

\begin{abstract}
In this study, the effects of kimchi powder on the quality properties of an emulsion type sausage made with irradiated pork meat were investigated. Raw ground pork ham was gamma-irradiated at 5 and $10 \mathrm{kGy}$, and the emulsion type sausage was then manufactured with the irradiated pork meat. The $\mathrm{pH}$ value was shown to increase by irradiation of raw material $(p<0.05)$. Samples containing kimchi powder had a lower $\mathrm{pH}$ value than other treatments, but no significant differences were observed. In a sensory evaluation, the scores of all the criteria were decreased with an increased irradiation dose of raw material, but samples containing kimchi powder had a higher sensory score than other treatments in all irradiation doses of raw material. The TBARS values were increased by irradiation of raw material and the samples containing kimchi powder had the highest value $(p<0.05)$. Odor substances analyzed by an electronic nose were increased with increased irradiation dose of raw material in all treatments, and samples containing kimchi powder showed a higher increase of odor substances than other treatments. Thus, this study demonstrated that kimchi powder was effective in eliminating the off-odor and flavor of sausages made with irradiated pork meat despite the increase of the TBARS value.
\end{abstract}

Key words: irradiation, sausage, kimchi powder, quality characteristics

\section{Introduction}

Irradiation is one of the best known methods to improve the safety of meat and meat products. The national legislations of over 55 countries have approved its use in sanitizing food (Farkas and Mohácsi-Farkas, 2011), including the Food and Drug Administration (FDA) in the U.S. (FDA, 1997). However, ionizing irradiation produces dose-dependent off-odor and off-flavor effects due to radiolytic free radicals, which promote lipid oxidation and produce volatile compounds in meat and meat products (Ahn, 2002; Jo and Ahn, 2000).

Previous studies have shown that medium to high dose

*Corresponding author: Cheon-Jei Kim, Department of Food Science and Biotechnology of Animal Resources, Konkuk University, Seoul 143-701, Korea. Tel: 82-2-450-3684, Fax: 82-2-444-6695, E-mail: kimcj@konkuk.ac.kr irradiation (5-20 kGy) was very effective in extending the shelf-life for ground raw pork and cooked pork patties; however, this treatment decreased the sensory quality of the meat due to the production of an off-flavor and lipid oxidation (Song et al., 2009).

Kimchi is a traditional Korean fermented food made of mainly leaf or root vegetable and other components including garlic, ginger, onion, red pepper, fermented shrimp or fish and so on. Kimchi has been shown to have antioxidant activity (Lee and Kunz, 2005), anticancer activity (Cho et al., 1999) and nutritional benefits due to its high content of dietary fiber (Park et al., 1996). In addition, kimchi can be used as a seasoning to enhance the flavor of other food products because its combination of pungent vegetables and spices gives it a unique flavor during fermentation (Cho, 2005), which has been described as a combination of saltiness, sweetness, sourness, spiciness and crunchy texture (Hong et al., 2007). 
However, kimchi has a high water content, which limits its use in a variety of food products. Recently, kimchi powder has been used in various products and was shown to improve the sensory properties of snacks (Cho et al., 2004), noodles (Cho et al., 2003), seafood dumplings (Kang et al., 2001), and breakfast sausages (Cho, 2005; Lee et al., 2008a, b). Lee et al. (2008a) investigated the effects of kimchi powder on the sensory properties of low-fat sausage and found that it could improve the flavor and color of meat products.

Various methods have recently been used to improve the sensory quality of irradiated meat and meat products such as additives, packaging methods and combinations of these methods (Ahn et al., 2000; Nam and Ahn, 2003a; Nam et al., 2006). The additives used for this purpose were primarily antioxidants, such as ascorbic acid (Lacroix et al., 2004), tocopherol (Nam and Ahn, 2003b; Nam and Ahn, 2007) and rosemary (Lee et al., 2005). However, few studies have attempted to mask the off-odor and flavor of irradiated meat products using kimchi powder. Therefore, the objective of this study was to evaluate the effect of adding kimchi powder to emulsion type sausage made with irradiated pork meat on the quality properties and eliminating radiolytic off-odor and off-flavor.

\section{Materials and Methods}

\section{Meat preparation and gamma irradiation}

Fresh pork hams and back fat were purchased in a local market. All subcutaneous, intramuscular fat and visible connective tissue were removed from the fresh pork muscles. Trimmed muscles were ground through an $8 \mathrm{~mm}$ plate, after which the ground tissue was placed in polyethylene bags, vacuum packed using a vacuum packaging system (FJ-500XL, Fugee Tech, Korea) and stored $-20^{\circ} \mathrm{C}$ until irradiation to minimize quality loss.

The meat was irradiated at 5 and $10 \mathrm{kGy}$ in a cobalt-60 irradiator (point source, AECL, IR-79, Nordion international, Canada) with source strength of $100 \mathrm{kCi}$ in Advanced Radiation Technology Institute of Korea Atomic Energy Research Institute (Korea). The dose rate was $70 \mathrm{kGy} /$ $\min$ at $18 \pm 0.5^{\circ} \mathrm{C}$. Dosimetry was performed using $5 \mathrm{~mm}$ diameter alanine dosimeters (Bruker Instruments, Germany), and the free-radical signal was measured using a Bruker EMS 104 EPR Analyzer. The actual dose was within $\pm 2 \%$ of the target dose. The irradiated ground pork meat was transferred to a $-20^{\circ} \mathrm{C}$ freezer and stored until required for product manufacture.

\section{Preparation of kimchi powder}

Kimchi powder was prepared as described by Lee et al. (2008b). Commercial Chinese cabbage kimchi was purchased from a local market (Chongga Kimchi, Daesang FNF, Korea). This kimchi was manufactured 1-2 d before the purchase date, and then fermented in the laboratory refrigerator to approach the optimal sensory condition in a period of $15 \mathrm{~d}$ at $4 \pm 1^{\circ} \mathrm{C}$ according to Hong and Park (1999). At the beginning of fermentation, the $\mathrm{pH}$ of kimchi averaged $\mathrm{pH}$ 5.4, and gradually decreased to $\mathrm{pH} 4.3$, packaged with PE/Nylon film bags with sealing.

The chemical composition of the kimchi, determined in triplicates according to the AOAC (1995) method was: $91.3 \mathrm{~g} / 100 \mathrm{~g}$ moisture, $2.2 \mathrm{~g} / 100 \mathrm{~g}$ protein, $0.5 \mathrm{~g} / 100 \mathrm{~g}$ fat, $0.85 \mathrm{~g} / 100 \mathrm{~g}$ ash, and $2.1 \mathrm{~g} / 100 \mathrm{~g}$ dietary fiber. Kimchi was blended with a cutter (C4 VV, Sirman, Italy) and then packed about $300 \mathrm{~g}$ of each bags and pressed flat for drying. The vacuum-packaged kimchi was immediately frozen at $-20 \pm 1^{\circ} \mathrm{C}$ until used. Hot air drying was carried out in a hot air dryer (Enex-Co-600, Enex, Korea) at $60 \pm 1^{\circ} \mathrm{C}$. The samples were dehydrated until they reached a constant weight $(<15 \%$ final moisture) for $12 \mathrm{~h}$ at the hot air dryer, and then finely ground to $<0.5 \mathrm{~mm}$ (35 mesh) in size. The powders were stored in a deep freezer $\left(-70^{\circ} \mathrm{C}\right)$ until further used.

\section{Manufacturing of emulsion type pork sausage}

Emulsion type pork sausage was manufactured with irradiated pork hams, pork back fat and additives (Table 1). Raw ground pork ham was homogenized and ground for $1 \mathrm{~min}$ in a silent cutter (Nr-963009, Scharfen, Germany). $1.5 \%$ salt was added to the meat and mixed for 1 min, back fat was added after $3 \mathrm{~min}$ and the batters were homogenized for $6 \mathrm{~min}$. A temperature probe (Kane-May, KM330, Germany) was used to monitor the temperature of the emulsion, which was maintained below $10^{\circ} \mathrm{C}$ during batter preparation. Batters were stuffed into collagen casings (approximate $16 \mathrm{~mm}$ diameter; \#180, NIPPI Inc., Japan) using a stuffer (Stuffer IS-8, Sirman, Italy), and samples were heating at $80^{\circ} \mathrm{C}$ until $75^{\circ} \mathrm{C}$ at core temperature for $30 \mathrm{~min}$ in smoke house and then cooled with cold water for $10 \mathrm{~min}$ until $10^{\circ} \mathrm{C}$ at core temperature. The produced samples were vacuum sealed in polyethylene bags and stored at $4^{\circ} \mathrm{C}$ during analysis.

\section{pH}

The $\mathrm{pH}$ values of sample were measured in a homogenate prepared with $5 \mathrm{~g}$ of sample and distilled water (20 $\mathrm{mL}$ ) using a pH meter (Model 340, Mettler-Toledo GmbH, 
Table 1. Formulations of emulsion type sausage made with irradiated pork meat manufactured with kimchi powder (unit: \%)

\begin{tabular}{lccc}
\hline \multirow{2}{*}{ Materials } & \multicolumn{3}{c}{ Treatments $^{1)}$} \\
\cline { 2 - 4 } & Control & OG & OGK \\
\hline Irradiated pork meat $^{2)}$ & 60 & 60 & 60 \\
Pork back fat & 20 & 20 & 20 \\
Ice water & 20 & 20 & 20 \\
Total & 100 & 100 & 100 \\
NPS & 1.50 & 1.50 & 1.50 \\
Sodium tri-poly phosphate & 0.30 & 0.30 & 0.30 \\
Ascorbic acid & 0.02 & 0.02 & 0.02 \\
ISP $^{4)}$ & 0.50 & 0.50 & 0.50 \\
MSG $^{5)}$ & 0.06 & 0.06 & 0.06 \\
Onion powder & 0 & 0.30 & 0.30 \\
Garlic powder $_{\text {Kimchi powder }}$ & 0 & 0.30 & 0.30 \\
\hline Control, sausages & 0 & 0 & 0.50 \\
\hline
\end{tabular}

${ }^{1)}$ Control, sausages with no spices; OG, sausage with $0.3 \%$ onion powder and $0.3 \%$ garlic powder; OGK, sausage with $0.3 \%$ onion powder, $0.3 \%$ garlic powder and $0.5 \%$ kimchi powder

${ }^{2)}$ Irradiated pork meat, raw ground pork ham gamma-irradiated at 0,5 , and $10 \mathrm{kGy}$, respectively

${ }^{3)} \mathrm{NPS}, 99.4 \% \mathrm{NaCl}$ containing $0.6 \%$ sodium nitrite

${ }^{4)}$ ISP, Isolated soy protein

${ }^{5)}$ MSG, Monosodium L-glutamate

Switzerland). All determinations were performed in triplicate.

\section{Color evaluation}

The color of sample was determined using a colorimeter (Minolta Chroma meter CR-210, Minolta Co., Japan; illuminate $\mathrm{C}$, calibrated with a white plate, CIE $\mathrm{L}^{*}=$ $\left.+97.83, \mathrm{CIE} \mathrm{a}^{*}=-0.43, \mathrm{CIE} \mathrm{b}^{*}=+1.98\right)$. Six measurements for each of five replicates were taken. Lightness (CIE L*value), redness (CIE $\mathrm{a}^{*}$ - value), and yellowness (CIE b*value) values were recorded.

\section{Texture profile analysis (TPA)}

The textural properties of sample were measured by a $0.25 \varnothing$ spherical probe attached to a texture analyzer (TAXT2i, Stable Micro Systems Ltd., England). The test conditions were as follows: stroke, $20 \mathrm{~g}$; test speed, $2 \mathrm{~mm} / \mathrm{s}$; distance, $10.0 \mathrm{~mm}$. Data were collected and analyzed regarding the hardness $(\mathrm{kg})$, springiness, cohesiveness, gumminess $(\mathrm{kg})$, and chewiness $(\mathrm{kg})$ values.

\section{Thiobarbituric acid-reactive substances (TBARS)}

TBARS values were obtained with slightly modified method of Witte et al. (1970). A $5 \mathrm{~g}$ sample was placed in the cup and $15 \mathrm{~mL}$ solution of $10 \%$ trichloroacetic acid (TCA) was added to the cup and homogenized for $1 \mathrm{~min}$ at 10,000 rpm using a homogenizer (AM-7, Nihonseiki Kaisha Ltd., Japan). The slurry was filtered through filter paper (Ø110 mm, Cat. No. 1001 110, Whatman International Ltd, England). $5 \mathrm{~mL}$ of the filtrate was pipette into a test tube, and $5 \mathrm{~mL}$ of fresh chilled $0.02 \mathrm{M} 2$-thiobarbituric acid solution was added to it. $5 \mathrm{~mL}$ of distilled water was added to the test tube and mixed with $5 \mathrm{~mL}$ of TBA solution for blank sample. All samples in test tubes were heated in a boiling water bath for $30 \mathrm{~min}$ to develop the color reaction and cooled to room temperature for 10 $\mathrm{min}$. The amount of color was measured in a UV spectrophotometer (Libra S22, Biochrom Ltd., England) at 529 $\mathrm{nm}$ to calculate the TBARS value. The $K$ value was calculated using 1,1,3,3,-tetraethoxypropane (Sigma) as the standard and TBARS values were calculated by multiplying the absorbance values by the $K$ values. The results were expressed as mg malonaldehyde (MDA)/kg sample.

\section{Sensory evaluation}

Sensory evaluations were performed in triplicate on each sample by sensory panelists. A trained twelve-member panel consisting of researchers from the department of Food Sciences and Biotechnology of Animal Resources at Konkuk University in Korea was used to evaluate the emulsion type cooked sausage made with irradiated pork meat. The samples were taken out from vacuum packaged bags, cut into $5 \mathrm{~mm}$ slices and served to the panels when samples were at room temperature. Panellists were presented with randomly coded samples and required to cleanse their palate between samples with water. Color ( $1=$ extremely undesirable, $10=$ extremely desirable), flavor ( $1=$ extremely undesirable, $10=$ extremely desirable), tenderness $(1=$ extremely tough, $10=$ extremely tender), juiciness ( $1=$ extremely dry, $10=$ extremely juicy), off-odor (1=extremely weak, $10=$ extremely strong), and overall acceptance $(1=$ extremely undesirable, $10=$ extremely desirable) of samples were evaluated using a 10-point descriptive scale. This analysis was conducted using the hedonic test described by Lee et al. (2008b).

\section{Electronic nose analysis}

An electronic nose zNose (Electronic sensor Technology, USA) with GC-SAW (Gas Chromatogram-Surface Acoustic Wave) sensor (SAW sensor, Electronic Sensor Technology, USA) was used. An aliquot of $10 \mathrm{~g}$ of sample was placed into a $40 \mathrm{~mL}$ septa-sealed vial. During analysis, the sample temperature was kept at $50^{\circ} \mathrm{C}$ in a water bath with large thermal inertia and each of SAW sensor, column, valve, inlet and trap were maintained at 
$30,60,120,150$, and $220^{\circ} \mathrm{C}$, respectively.

The SAW sensor consists of an uncoated acoustic resonator bonded to a Peltier thermoelectric heat pump to heat or cool the quartz substrate. The vapors dispersed from the column reach the sensor and affect the vibration, which create frequency response by measuring time and amount of each chemical. Software incorporated in the instrument displays the sensor frequency and chromatogram derived from frequency (Kim et al., 2010).

\section{Statistical analysis}

An analysis of variance was performed on all the variables measured using the general linear model (GLM) procedure of the SAS statistical package (1999). Duncan's multiple range test $(p<0.05)$ was used to determine the differences between treatment means.

\section{Results and Discussion}

\section{pH and color}

The $\mathrm{pH}$ and color of emulsion type cooked sausage made with irradiated pork meat are shown in Table 2. Previously, Lee et al. (2008a, 2008b) have reported that the raw $\mathrm{pH}$ value of kimchi powder affected the final $\mathrm{pH}$ of breakfast sausages. Samples containing kimchi powder had statistically equal $\mathrm{pH}$ value with the control and $\mathrm{OG}$ when the raw material was irradiated at 0 and $5 \mathrm{kGy}$, and the $\mathrm{pH}$ value when the raw material was irradiated at 10 kGy was significantly lower than the others $(p<0.05)$.

Irradiation of raw material and the addition of kimchi powder had no significant effect on the lightness $\left(\mathrm{CIE} \mathrm{L}^{*}\right)$ of the sausages. The redness (CIE a*) of the sausages was decreased by irradiation of raw material $(p<0.05)$. Previous studies showed that irradiation increased the redness of raw pork (Nanke et al., 1998; Ohene-Adjei et al., 2004), and similar trend was observed with raw pork (no data shown here). However, the redness of both the sausage batter and final product were decreased by irradiation of raw material $(p<0.05)$. Nanke et al. (1998) reported that the red color in irradiated vacuum packaged pork was largely due to oxymyoglobin $\left(\mathrm{MbO}_{2}\right)$, and Groninger et al. (1956) suggested that $\mathrm{MbO}_{2}$ was formed by the reaction of hydroxyl radicals with metmyoglobin $\left(\mathrm{MbFe}^{3+}\right)$ when no oxygen was present. Therefore, it is possible that denatured myoglobin in the irradiated raw pork impeded normal development of cured meat color formation (nitrosomyoglobin). Samples with kimchi powder had a higher redness value than the other samples. The yellowness (CIE $\mathrm{b}^{*}$ ) was the highest in samples containing kimchi powder regardless of irradiation dose of raw material $(p<0.05)$. It is believed that the increase of redness and yellowness in OGK was due to the red and yellowish color of the kimchi powder. Similar results have been reported by Lee et al. (2008a, 2008b) where the addition of kimchi powder was shown to increase the red color and yellow color of breakfast sausage.

\section{Texture profile analysis (TPA)}

The texture properties of emulsion type cooked sausage made with irradiated pork meat containing kimchi pow-

Table 2. Effect of kimchi powder on $\mathrm{pH}$ and color evaluation of emulsion type cooked sausage made with irradiated pork meat

\begin{tabular}{|c|c|c|c|c|}
\hline \multirow{2}{*}{ Traits } & \multirow{2}{*}{$\begin{array}{l}\text { Irradiation dose } \\
\qquad(\mathrm{kGy})\end{array}$} & \multicolumn{3}{|c|}{ Treatments $^{1)}$} \\
\hline & & Control & OG & OGK \\
\hline \multirow{3}{*}{$\mathrm{pH}$} & 0 & $6.19 \pm 0.02^{c}$ & $6.18 \pm 0.03^{c}$ & $6.18 \pm 0.02^{\mathrm{c}}$ \\
\hline & 5 & $6.27 \pm 0.03^{\mathrm{b}}$ & $6.28 \pm 0.02^{\mathrm{b}}$ & $6.26 \pm 0.02^{\mathrm{b}}$ \\
\hline & 10 & $6.40 \pm 0.04^{\mathrm{Aa}}$ & $6.38 \pm 0.02^{\mathrm{ABa}}$ & $6.34 \pm 0.02^{\mathrm{Ba}}$ \\
\hline \multirow{3}{*}{ CIE L* } & 0 & $72.91 \pm 0.44$ & $73.42 \pm 1.01$ & $74.28 \pm 0.59$ \\
\hline & 5 & $72.26 \pm 0.89$ & $72.25 \pm 1.87$ & $71.23 \pm 1.00$ \\
\hline & 10 & $73.23 \pm 1.73$ & $72.90 \pm 2.49$ & $72.32 \pm 2.64$ \\
\hline \multirow{3}{*}{ CIE a* } & 0 & $7.82 \pm 0.23^{\mathrm{a}}$ & $7.44 \pm 0.47^{\mathrm{a}}$ & $7.85 \pm 0.52^{\mathrm{a}}$ \\
\hline & 5 & $6.66 \pm 0.48^{\mathrm{Bb}}$ & $6.58 \pm 0.56^{\mathrm{Bb}}$ & $7.67 \pm 0.29^{\mathrm{Aab}}$ \\
\hline & 10 & $5.53 \pm 0.42^{\mathrm{Bc}}$ & $6.01 \pm 0.30^{\mathrm{Bb}}$ & $7.21 \pm 0.11^{\mathrm{Ab}}$ \\
\hline \multirow{3}{*}{$\mathrm{CIE} \mathrm{b}^{*}$} & 0 & $7.61 \pm 0.72^{\mathrm{B}}$ & $7.92 \pm 0.64^{\mathrm{B}}$ & $14.06 \pm 0.28^{\mathrm{A}}$ \\
\hline & 5 & $7.33 \pm 0.52^{\mathrm{B}}$ & $7.28 \pm 0.24^{\mathrm{B}}$ & $14.03 \pm 0.92^{\mathrm{A}}$ \\
\hline & 10 & $8.35 \pm 0.69^{\mathrm{B}}$ & $7.21 \pm 0.11^{\mathrm{B}}$ & $14.12 \pm 0.40^{\mathrm{A}}$ \\
\hline
\end{tabular}

All values are mean $\pm \mathrm{SD}$ of the three replicates.

${ }_{\mathrm{A}, \mathrm{B}}$ Means sharing different letters in the same row are significantly different $(p<0.05)$.

${ }^{\mathrm{a}-\mathrm{c}}$ Means sharing different letters in the same column are significantly different $(p<0.05)$.

${ }^{1)}$ Treatments: Control, sausages with no spices; OG, sausage with $0.3 \%$ onion powder and $0.3 \%$ garlic powder; OGK, sausage with $0.3 \%$ onion powder, $0.3 \%$ garlic powder and $0.5 \%$ kimchi powder 
Table 3. Texture properties of emulsion type cooked sausage made with irradiated pork meat manufactured with kimchi powder

\begin{tabular}{|c|c|c|c|c|}
\hline \multirow{2}{*}{ Traits } & \multirow{2}{*}{$\begin{array}{l}\text { Irradiation dose } \\
\qquad(\mathrm{kGy})\end{array}$} & \multicolumn{3}{|c|}{ Treatments $^{1)}$} \\
\hline & & Control & OG & OGK \\
\hline \multirow{3}{*}{ Hardness (kg) } & 0 & $0.52 \pm 0.03^{\mathrm{a}}$ & $0.53 \pm 0.06^{\mathrm{a}}$ & $0.56 \pm 0.08$ \\
\hline & 5 & $0.42 \pm 0.04^{\mathrm{Bc}}$ & $0.46 \pm 0.06^{\mathrm{Bb}}$ & $0.54 \pm 0.04^{\mathrm{A}}$ \\
\hline & 10 & $0.46 \pm 0.03^{\mathrm{Bb}}$ & $0.49 \pm 0.06^{\mathrm{ABab}}$ & $0.52 \pm 0.05^{\mathrm{A}}$ \\
\hline \multirow{3}{*}{ Springiness } & 0 & $0.94 \pm 0.05$ & $0.93 \pm 0.04^{\mathrm{b}}$ & $0.94 \pm 0.02$ \\
\hline & 5 & $0.96 \pm 0.03$ & $0.96 \pm 0.02^{\mathrm{a}}$ & $0.96 \pm 0.03$ \\
\hline & 10 & $0.95 \pm 0.02$ & $0.94 \pm 0.02^{\mathrm{ab}}$ & $0.94 \pm 0.03$ \\
\hline \multirow{3}{*}{ Cohesiveness } & 0 & $0.48 \pm 0.03^{\mathrm{B}}$ & $0.50 \pm 0.08^{\mathrm{B}}$ & $0.58 \pm 0.09^{\mathrm{A}}$ \\
\hline & 5 & $0.46 \pm 0.07^{\mathrm{B}}$ & $0.47 \pm 0.04^{\mathrm{B}}$ & $0.53 \pm 0.02^{\mathrm{A}}$ \\
\hline & 10 & $0.51 \pm 0.04$ & $0.52 \pm 0.05$ & $0.53 \pm 0.03$ \\
\hline \multirow{3}{*}{ Gumminess (kg) } & 0 & $0.25 \pm 0.02^{\mathrm{Ba}}$ & $0.26 \pm 0.04^{\mathrm{Ba}}$ & $0.32 \pm 0.08^{\mathrm{A}}$ \\
\hline & 5 & $0.19 \pm 0.03^{\mathrm{Bb}}$ & $0.22 \pm 0.03^{\mathrm{Bb}}$ & $0.29 \pm 0.01^{\mathrm{A}}$ \\
\hline & 10 & $0.23 \pm 0.02^{\mathrm{Ba}}$ & $0.25 \pm 0.04^{\mathrm{ABab}}$ & $0.28 \pm 0.03^{\mathrm{A}}$ \\
\hline \multirow{3}{*}{ Chewiness (kg) } & 0 & $0.24 \pm 0.02^{\mathrm{B}}$ & $0.24 \pm 0.03^{\mathrm{B}}$ & $0.30 \pm 0.07^{\mathrm{A}}$ \\
\hline & 5 & $0.18 \pm 0.03^{\mathrm{B}}$ & $0.21 \pm 0.03^{\mathrm{B}}$ & $0.27 \pm 0.02^{\mathrm{A}}$ \\
\hline & 10 & $0.22 \pm 0.02^{\mathrm{B}}$ & $0.24 \pm 0.05^{\mathrm{AB}}$ & $0.26 \pm 0.02^{\mathrm{A}}$ \\
\hline
\end{tabular}

All values are mean \pm SD of the three replicates.

${ }^{\mathrm{A}, \mathrm{B}}$ Means sharing different letters in the same row are significantly different $(p<0.05)$.

${ }^{\mathrm{a}-\mathrm{c}}$ Means sharing different letters in the same column are significantly different $(p<0.05)$.

${ }^{1)}$ Treatments: Control, sausages with no spices; OG, sausage with $0.3 \%$ onion powder and $0.3 \%$ garlic powder; OGK, sausage with $0.3 \%$ onion powder, $0.3 \%$ garlic powder and $0.5 \%$ kimchi powder

der is shown in Table 3. The hardness was decreased by irradiation. $0 \mathrm{kGy}-\mathrm{OGK}$ had the highest value and the 5 kGy-Control sample had the lowest value. Song et al. (2009) also reported that the hardness value decreased by irradiation because the ionizing energy weakened the protein linkages, resulting in complete or partial protein denaturation in skeletal muscles and connective tissues (Horowits et al., 1986). OGK was harder than the control and OG but, only 5 and $10 \mathrm{kGy}$ treatments showed significant difference $(p<0.05)$. This may be due to the effect of irradiation on the dietary fibers in kimchi powder. In this experiment, the OGK sausage mass contained $0.5 \%$ of kimchi powder (total $1.1 \%$ of spices) whereas the control had no spices and the total mass percent of spice in OG was $0.6 \%$. Lee et al. (2008a) reported that the addition of kimchi powder increased the hardness of breakfast sausage and this increase was dependent on of the amount of added kimchi powder. Springiness did not shown differences among treatments. Cohesiveness, gumminess, and chewiness were significantly higher in OGK than the control and OG $(p<0.05)$. Similar results were observed by Lee et al. (2008b), who reported that the gumminess and chewiness was significantly higher in breakfast sausages subjected to different drying methods and containing different concentrations of kimchi powder than the control.

\section{Thiobarbituric acid reactive substance (TBARS)}

The TBARS value of emulsion type cooked sausage made with irradiated pork meat is shown in Fig. 1. Lipid oxidation was promoted by irradiation of raw material, and all treatments were shown the increase of TBARS values. Only samples irradiated at $10 \mathrm{kGy}$ had significantly higher TBARS values than non-irradiated samples. However, all samples showed a low degree of lipid oxidation and the TBARS values were below $0.2 \mathrm{MDA} \mathrm{mg} / \mathrm{kg}$, which was far below the threshold levels for unacceptable rancidity in cooked meat (0.6-2.0 MDA mg/kg) (Greene and Cumuze, 1981). This was the case because our raw pork meat was irradiated in an oxygen free condition in which propagation and formation of free radicals were limited (Nortjé et al., 2005). OG showed higher TBARS value than control and lower than OGK. Onion and garlic are generally known having antioxidant effects in previous studies (Cao et al., 1996; Yin and Cheng, 1998). However, according to the results reported by Park et al., (2008), garlic and onion powder treatment had antioxidant effect in pork belly whereas did not have the effect in pork loin. Thus, consistent antioxidant effect was not observed. OGK showed higher TBARS values than the control and OG regardless of the irradiation dose of raw material. Antioxidant properties of kimchi come from its variety ingredients and biological compounds produced 


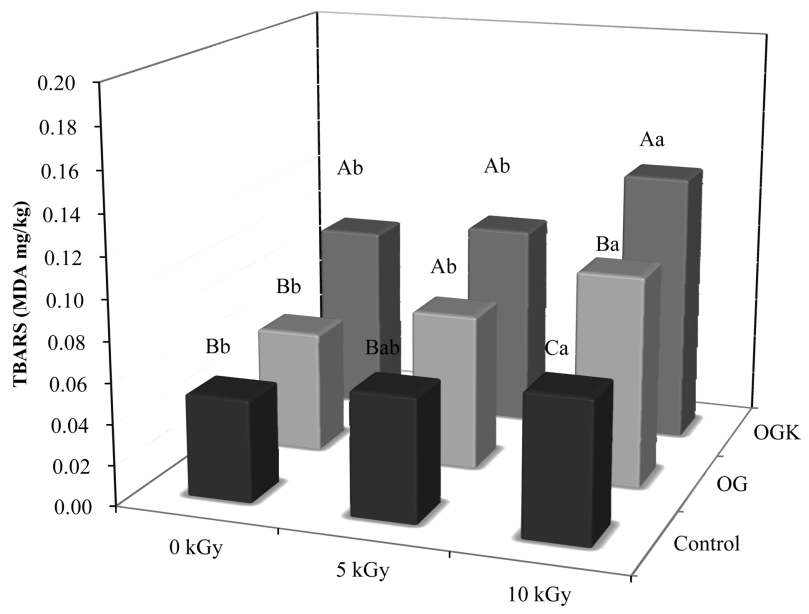

Fig. 1. TBARS value of emulsion type cooked sausage made with irradiated pork meat manufactured with kimchi powder. ${ }^{A-C}$ Means in the treatments with different letters are significantly different $(p<0.05) .{ }^{\mathrm{a}, \mathrm{b}}$ Means in the treatments with different letters are significantly different $(p<0.05)$.

during fermentation. Chinese cabbage, the main ingredient of kimchi, contains iron $(0.06 \mathrm{mg} / 100 \mathrm{~g})$, copper $(0.34 \mathrm{mg} / 100 \mathrm{~g})$ and manganese $(0.28 \mathrm{mg} / 100 \mathrm{~g})$ (Lee and Kunz, 2005), thus it could be assumed that the presence of transition metal ions in Chinese cabbage affected the oxidation of flavonoids in kimchi. Cao et al. (1997) found that flavonoids act as antioxidants against peroxyl and hydroxyl radicals and act as prooxidants in the presence of $\mathrm{Cu}^{2+}$.

Lee and Kunz (2005) reported the antioxidant effect of kimchi and kimchi powder depends on its fermentation temperature. They explained that Chinese cabbage kimchi fermented at $20^{\circ} \mathrm{C}$ was able to retard lipid oxidation, whereas Chinese cabbage kimchi fermentation at $7^{\circ} \mathrm{C}$ displayed no antioxidant activity because the kimchi fermented at high temperature $\left(20^{\circ} \mathrm{C}\right)$ had greater amount of antioxidant enzyme possessing microorganisms such as Staphylococcus, Micrococcus and some lactic acid bacteria. Thus, low fermentation temperature of kimchi might be one of the reasons to increase the TBARS value in this study.

\section{Sensory evaluation}

Sensory evaluation of emulsion type cooked sausage made with irradiated pork meat is shown in Table 4. Irradiation of raw material decreased the flavor and overall acceptance, and increased off-odor $(p<0.05)$. The tenderness and juiciness were not affected by irradiation of raw material on the sensory evaluation, while texture profile

Table 4. Sensory evaluation of emulsion type cooked sausage made with irradiated pork meat manufactured with kimchi powder

\begin{tabular}{|c|c|c|c|c|}
\hline \multirow{2}{*}{ Traits } & \multirow{2}{*}{$\begin{array}{l}\text { Irradiation dose } \\
\qquad(\mathrm{kGy})\end{array}$} & \multicolumn{3}{|c|}{ Treatments ${ }^{1)}$} \\
\hline & & Control & OG & OGK \\
\hline \multirow{3}{*}{ Color } & 0 & $8.10 \pm 0.74^{\mathrm{Ba}}$ & $8.30 \pm 0.67^{\mathrm{ABa}}$ & $8.80 \pm 0.42^{\mathrm{A}}$ \\
\hline & 5 & $7.80 \pm 0.42^{\mathrm{Bab}}$ & $7.95 \pm 0.60^{\mathrm{Bab}}$ & $8.70 \pm 0.48^{\mathrm{A}}$ \\
\hline & 10 & $7.30 \pm 0.82^{\mathrm{Bb}}$ & $7.60 \pm 0.70^{\mathrm{Bb}}$ & $8.40 \pm 0.52^{\mathrm{A}}$ \\
\hline \multirow{3}{*}{ Flavor } & 0 & $7.90 \pm 0.74^{\mathrm{Ba}}$ & $8.30 \pm 0.67^{\mathrm{ABa}}$ & $8.60 \pm 0.84^{\mathrm{Aa}}$ \\
\hline & 5 & $6.90 \pm 0.74^{\mathrm{Bb}}$ & $7.10 \pm 0.32^{\mathrm{Bb}}$ & $8.10 \pm 0.57^{\mathrm{Aa}}$ \\
\hline & 10 & $5.90 \pm 0.57^{\mathrm{Cc}}$ & $6.85 \pm 0.67^{\mathrm{Bb}}$ & $7.90 \pm 0.74^{\mathrm{Ab}}$ \\
\hline \multirow{3}{*}{ Tenderness } & 0 & $8.05 \pm 0.37$ & $8.10 \pm 0.32$ & $8.10 \pm 0.32$ \\
\hline & 5 & $7.90 \pm 0.57$ & $8.00 \pm 0.47$ & $8.00 \pm 0.47$ \\
\hline & 10 & $7.80 \pm 0.79$ & $7.80 \pm 0.42$ & $8.10 \pm 0.32$ \\
\hline \multirow{3}{*}{ Juiciness } & 0 & $7.85 \pm 0.34^{\mathrm{B}}$ & $8.00 \pm 0.00^{\mathrm{AB}}$ & $8.25 \pm 0.42^{\mathrm{A}}$ \\
\hline & 5 & $7.90 \pm 0.57^{\mathrm{A}}$ & $7.90 \pm 0.57^{\mathrm{A}}$ & $8.00 \pm 0.47^{\mathrm{A}}$ \\
\hline & 10 & $7.60 \pm 0.70^{\mathrm{B}}$ & $7.80 \pm 0.42^{\mathrm{AB}}$ & $8.20 \pm 0.42^{\mathrm{A}}$ \\
\hline \multirow{3}{*}{ Off-odor } & 0 & $1.60 \pm 0.97^{\mathrm{Ab}}$ & $1.20 \pm 0.63^{\mathrm{ABc}}$ & $0.40 \pm 0.52^{\mathrm{Bc}}$ \\
\hline & 5 & $4.10 \pm 0.74^{\mathrm{Aa}}$ & $3.50 \pm 0.53^{\mathrm{Ab}}$ & $2.00 \pm 0.94^{\mathrm{Bb}}$ \\
\hline & 10 & $4.60 \pm 0.70^{\mathrm{Aa}}$ & $4.20 \pm 0.79^{\mathrm{Aa}}$ & $2.90 \pm 0.88^{\mathrm{Ba}}$ \\
\hline \multirow{3}{*}{ Overall acceptance } & 0 & $8.05 \pm 0.60^{\mathrm{Ba}}$ & $8.20 \pm 0.63^{\mathrm{Ba}}$ & $8.90 \pm 0.32^{\mathrm{Aa}}$ \\
\hline & 5 & $6.60 \pm 0.84^{\mathrm{Bb}}$ & $6.70 \pm 0.67^{\mathrm{Bb}}$ & $7.90 \pm 0.32^{\mathrm{Ab}}$ \\
\hline & 10 & $6.20 \pm 0.63^{\mathrm{Bb}}$ & $6.70 \pm 0.48^{\mathrm{Bb}}$ & $7.90 \pm 0.74^{\mathrm{Ab}}$ \\
\hline
\end{tabular}

All values are mean $\pm \mathrm{SD}$ of the three replicates.

${ }^{\mathrm{A}, \mathrm{B}}$ Means sharing different letters in the same row are significantly different $(p<0.05)$.

${ }^{\mathrm{a}-\mathrm{c}}$ Means sharing different letters in the same column are significantly different $(p<0.05)$.

${ }^{1)}$ Treatments: Control, sausages with no spices; OG, sausage with $0.3 \%$ onion powder and $0.3 \%$ garlic powder; OGK, sausage with $0.3 \%$ onion powder, $0.3 \%$ garlic powder and $0.5 \%$ kimchi powder 
Table 5. Total amount of flavor components in emulsion type cooked sausages made with irradiated pork meat manufactured with kimchi powder by electronic nose

(unit: Kct/s)

\begin{tabular}{cccc}
\hline \hline \multirow{2}{*}{ Irradiation dose (kGy) } & \multicolumn{3}{c}{ Treatments $^{\text {1) }}$} \\
\cline { 2 - 4 } & Control & OG & OGK \\
\hline 0 & $3148.67 \pm 158.574^{\mathrm{Bc}}$ & $5340.50 \pm 187.084^{\mathrm{Ac}}$ & $5536.83 \pm 173.995^{\mathrm{Ac}}$ \\
5 & $4808.83 \pm 149.780^{\mathrm{Cb}}$ & $5713.33 \pm 186.748^{\mathrm{Bb}}$ & $6120.50 \pm 130.997^{\mathrm{Ab}}$ \\
\hline
\end{tabular}

All values are mean \pm SD of the three replicates.

${ }^{\mathrm{A}, \mathrm{B}}$ Means sharing different letters in the same row are significantly different $(p<0.05)$.

${ }^{\mathrm{a}-\mathrm{c}}$ Means sharing different letters in the same column are significantly different $(p<0.05)$.

${ }^{1)}$ Treatments: Control, sausages with no spices; OG, sausage with $0.3 \%$ onion powder and $0.3 \%$ garlic powder; OGK, sausage with $0.3 \%$ onion powder, $0.3 \%$ garlic powder and $0.5 \%$ kimchi powder

analysis showed significant decrease for hardness $(p<$ 0.05 ). Color preference was decreased by irradiation of raw material, and OGK had the highest preference scores regardless of irradiation of raw material $(p<0.05)$. OGK had higher flavor score and lower off-odor score than OG, followed by the control $(p<0.05)$. OGK had a higher overall acceptance than OG, followed by the control $(p<$ 0.05 ) but, there was no significant difference between the control and OG. $0 \mathrm{kGy}$-OGK was the best in terms of low off-odor, high flavor and overall acceptance criteria, and this result indicated that kimchi powder did not increase the preference of sausage manufactured with irradiated meat as same as sausage manufactured with non-irradiated meat. However, $5 \mathrm{kGy}$-OGK and $10 \mathrm{kGy}$-OGK were shown higher overall acceptance score than $5 \mathrm{kGy}-\mathrm{Con}-$ trol, OG and $10 \mathrm{kGy}$-Control, OG, respectively $(p<0.05)$. Despite low TBARS values of all samples, panelists reported a high off-odor and low flavor scores for the samples made with irradiated meat. This indicates that the characteristic odor of irradiated meat was distinctly different from the rancidity off-odor produced by lipid oxidation (Nam and Ahn, 2003a). Therefore, it can be concluded that kimchi powder masked the irradiation induced off-odor and flavor in sausage made with irradiated pork meat.

\section{Electronic nose analysis}

Electronic noses discriminate complex odors using a sensor array and it can precisely detect and distinguish odors in complex samples (Peris and Escuder-Gilabert, 2009). The E-nose with the GC-SAW sensor has both advantages of a GC and SAW sensor, where GC has the ability to separate and identify volatiles and the SAW sensor has a comparatively high sensibility and is able to measure samples in a short time (Yoon et al., 2005). To get an overall view of data, the sum of each chemical in chromatogram was found (Table 5). The total amount of flavor components was increased by irradiation of raw material $(p<0.05)$, and OGK had the highest value followed by OG and the control. Han et al. (2009) reported that the total amount of odor substances was increased by irradiation, which was similar to the results reported in this study.

In conclusion, this study demonstrated that addition of kimchi powder to emulsion type sausage made with irradiated pork meat improved the sensory acceptance of the sausage. Samples containing kimchi powder had the lowest off-odor scores and the highest flavor and overall acceptance scores in sausages manufactured with irradiated pork meat despite higher TBARS value of OGK, which indicates that the kimchi powder effectively masked the off-odor and off-flavor. TBARS value was slightly increased by addition of kimchi power. The redness and yellowness of sausage were increased and the lightness of sausage was not affected by addition of kimchi powder. Therefore, kimchi powder has the potential to be used a seasoning material in order to eliminate radiolytic off-odor of irradiated meat products.

\section{Acknowledgements}

This research was supported by Ministry of Education and Human Resources Development by the Korean Government (2011-0002256). The authors were also partially supported by the Brain Korean 21 (BK 21) Project from the Ministry of Education and Human Resources Development, Republic of Korea.

\section{References}

1. Ahn, D. U. (2002) Production of volatiles from amino acid homopolymers by irradiation. J. Food Sci. 67, 419-426.

2. Ahn, D. U., Jo, C., Du, M., Olson, D. G., and Nam, K. C. (2000) Quality characteristics of pork patties irradiated and stored in different packaging and storage conditions. Meat Sci. 56, 203-209.

3. AOAC (1995) Official methods of analysis. 16th ed, Associ- 
ation of Official Analytical Chemists, Washington, DC.

4. Cao, G., Sofic, E., and Prior, R. L. (1997) Antioxidant and prooxidant behavior of flavonoids: structure-activity relationships. Free Radical Bio. Med. 22, 749-760.

5. Cao, G., Sofic, E., and Prior, R. L. (1996) Antioxidant capacity of tea and common vegetables. J. Agric. Food Chem. 44, 3426-3431.

6. Cho, E. J., Rhee, S. H., Kang, K. S., and Park, K. Y. (1999) In vitro anticancer effect of Chinese cabbage kimchi fractions. J. Korean Soc. Food Sci. Nutr. 28, 1326-1331.

7. Cho, Y. B. (2005) Development of breakfast sausage prepared with freeze-dried kimchi powder. Korean J. Food Cult. 20, 391-396.

8. Cho, Y. B. and Kang, B. N. (2003) Effect of analysis in the by taste and quality freeze-dried kimchi powder adding of noodles. Korean J. Culinary Res. 9, 115-126.

9. Cho, Y. B., Park, W. P., Hur, M. S., and Lee, Y. B. (2004) Effect of adding freeze-dried kimchi powder on flavor and taste of kimchi snacks. Korean J. Food Sci. Technol. 36, 919923.

10. Farkas, J. and Mohácsi-Farkas, C. (2011) History and future of food irradiation. Trends Food Sci. Technol. 22, 121-126.

11. FDA (1997) Irradiation in the production, processing and handling of food. Fed. Reg. 62, 232, 64107-64121.

12. Greene, B. E. and Cumuze, T. H. (1981) Relationship between TBA numbers and inexperienced panelists' assessments of oxidized flavor in cooked beef. J. Food Sci. 47, 52-58.

13. Groninger, H. S., Tappel, A. L., and Knapp, F. W. (1956) Some chemical and organoleptic changes in gamma irradiated meats. Food Res. 21, 555-564.

14. Han, I. J., Park, J. S., Choi, J. I., Kim, J. H., Song, B. S., Yoon, Y., Byun, M. W., Chun, S. S. and Lee, J. W. (2009) Change in flavor patterns of gamma irradiated raw oysters and oyster cooking drip determined using an electric nose. Korean $J$. Fish Aquat. Sci. 42, 209-214.

15. Hong, S. I. and Park, W. S. (1999) Development of color indicators for kimchi packaging. J. Food Sci. 64, 255-257.

16. Hong, S. P., Kim, E. M., Yang, J. N., and Ahn, D. U. (2007) Effect of irradiation on the quality characteristics of lyophilized kimchi powder. Korean J. Food Sci. Technol. 39, 614-618.

17. Horowits, R., Kempner, E. S., Bisher, M. E., and Podolsky, R. J. (1986) A physiological role for titin and nebulin in sketal muscle. Nature 323, 160-164.

18. Jo, C. and Ahn, D. U. (2000) Volatiles and oxidative changes in irradiated pork sausage with different fatty acid composition and tocopherol content. J. Food Sci. 65, 270-275.

19. Kang, K. S., Kim, Y. T., Lee, S. M., and Joo, O. S. (2001) Preservative effect of kimchi during storage of seafood bun. Korean J. Posthar. Sci. Technol. 8, 393-398.

20. Kim, G., Lee, K., Son J., and Kim, H. J. (2010) Analysis of Salmonella contaminated beef odor using an electronic nose. Korean J. Food Sci. Ani. Resour. 30, 185-189.

21. Lacroix, M., Ouattara, B., Saucier, L., Giroux, M., and Smoragiewicz, W. (2004) Effect of gamma irradiation in presence of ascorbic acid on microbial composition and TBARS con- centration of ground beef coated with an edible active coating. Radiat. Phys. Chem. 71, 71-75.

22. Lee, J. W., Park, K. S., Kim, J. G., Oh, S. H., Lee, Y. S., Kim, J. H., and Byun, M. W. (2005) Combined effect of gamma irradation and rosemary extract on the shelf-life of a readyto-eat hamburger steak. Radiat. Phys. Chem. 72, 49-56.

23. Lee, J. Y. and Kunz, B. (2005) The antioxidant properties of baechu-kimchi and freeze-dried kimchi-powder in fermented sausages. Meat Sci. 69, 741-747.

24. Lee, M. A., Han, D. J., Choi, J. H., Choi, Y. S., Kim, H. Y., Jeong, J. Y., Paik, H. D., and Kim, C. J. (2008a) Effect of hot air dried kimchi powder on the quality characteristics of lowfat sausages. Korean J. Food Sci. Ani. Resour. 26, 146-153.

25. Lee, M. A., Han, D. J., Jeong, J. Y., Choi, J. H., Choi, Y. S., Kim, H. Y., Paik, H. D., and Kim, C. J. (2008b) Effect of kimchi powder level and drying methods on quality characteristics of breakfast sausage. Meat Sci. 80, 708-714.

26. Nam, K. C. and Ahn, D. U. (2003a) Combination of aerobic and vacuum packaging to control lipid oxidation and offodor volatiles of irradiated raw turkey breast. Meat Sci. 63, 389-395.

27. Nam, K. C. and Ahn, D. U. (2003b) Use of antioxidants to reduce lipid oxidation and off-odor volatiles of irradiated pork homogenates and patties. Meat Sci. 63, 1-8.

28. Nam, K. C. and Ahn, D. U. (2007) Effect of oleoresin-tocopherol combinations on lipid oxidation, off-odor, and color of irradiated raw and cooked pork patties. Meat Sci. 75, 6170.

29. Nam, K. C., Ko, K. Y., Min, B. R., Ismail, H., Lee, E. J., Cordray, J., and Ahn, D. U. (2006) Influence of rosemarytocopherol/packaging combination on meat quality and the survival of pathogens in restructured irradiated pork loins. Meat Sci. 74, 380-387.

30. Nanke, K. E., Sebranek, J. G., and Olson, D. G. (1998) Color characteristics of irradiated vacuum-packaged pork, beef, and turkey. J. Food Sci. 63, 1001-1006.

31. Nortjé, K., Buys, E. M., and Minnarr, A. (2005) Effect of ãirradiation on the sensory quality of moist beef biltong. Meat Sci. 71, 603-611.

32. Ohene-Adjei, S., Bertol, T., Hyun, Y., Ellis, M., McKeith, F. K., and Brewer, M. S. (2004) Effect of vitamin E, low dose irradiation and display time on the quality of pork. Meat Sci. 68, 19-26.

33. Park, K. Y., Ha, J. O., and Rhee, S. H. (1996) A study on the contents of dietary fibers and crude fiber in kimchi ingredients and kimchi. J. Korean Soc. Food Nutr. 25, 69-75.

34. Park, S. Y., Yoo, S. S., Shim, J. H., and Chin, K. B. (2008) Physicochemical properties, and antioxidant and antimicrobial effects of garlic and onion powder in fresh pork belly and loin during refrigerated storage. J. Food Sci. 73, 577584.

35. Peris, M. and Escuder-Gilabert, L. (2009) A $21^{\text {st }}$ century technique for food control: Electronic noses. Anal. Chim. Acta 638, 1-15.

36. SAS (1999) SAS user's guide: Basic statistical analysis. SAS Institute Inc., Cary, NC, USA. 
37. Song, B. S., Park, J. G., Kim, W. G., Kim, J. H., Choi, J. I., Yoon, Y., Byun, M. W., Kim, C. J., and Lee, J. W. (2009) Comparision of the quality of gamma ray-or electron beamirradiated minced pork and pork patties. Korean J. Food Sci. Ani. Resour. 29, 194-202.

38. Witte, V. C., Krause, G. F., and Bailey, M. F. (1970) A new extraction methods for determining 2-thiobarbituric acid values of pork and beef during storage. J. Food Sci. 35, 582-
585.

39. Yin, M. and Cheng, W. (1998) Antioxidant activity of several Allium members. J. Agric. Food Chem. 46, 4097-4101.

40. Yoon, A. R., Han, K. Y., Oh, S. Y., and Noh, B. S. (2005) Prediction of rancidity for the heated rapeseed oil using the electronic nose. Food Eng. Progress 9, 309-319.

(Received 2011.7.1/Revised 1st 2011.8.22, 2nd 2011.8.31, 3rd 2011.9.14/Accepted 2011.9.15) 